\title{
Teacher design knowledge for technology enhanced learning: an ecological framework for investigating assets and needs
}

Citation for published version (APA):

McKenney, S., Kali, Y., Mauriskite, L., \& Voogt, J. (2015). Teacher design knowledge for technology enhanced learning: an ecological framework for investigating assets and needs. Instructional Science, 43(2), 181-202. https://doi.org/10.1007/s11251-014-9337-2

DOI:

10.1007/s11251-014-9337-2

Document status and date:

Published: 01/03/2015

Document Version:

Early version, also known as pre-print

Document license:

CC BY-SA

Please check the document version of this publication:

- A submitted manuscript is the version of the article upon submission and before peer-review. There can be important differences between the submitted version and the official published version of record. People interested in the research are advised to contact the author for the final version of the publication, or visit the DOI to the publisher's website.

- The final author version and the galley proof are versions of the publication after peer review.

- The final published version features the final layout of the paper including the volume, issue and page numbers.

Link to publication

\section{General rights}

Copyright and moral rights for the publications made accessible in the public portal are retained by the authors and/or other copyright owners and it is a condition of accessing publications that users recognise and abide by the legal requirements associated with these rights.

- Users may download and print one copy of any publication from the public portal for the purpose of private study or research.

- You may not further distribute the material or use it for any profit-making activity or commercial gain

- You may freely distribute the URL identifying the publication in the public portal.

If the publication is distributed under the terms of Article $25 \mathrm{fa}$ of the Dutch Copyright Act, indicated by the "Taverne" license above, please follow below link for the End User Agreement:

https://www.ou.nl/taverne-agreement

Take down policy

If you believe that this document breaches copyright please contact us at:

pure-support@ou.nl

providing details and we will investigate your claim.

Downloaded from https://research.ou.nl/ on date: 26 Apr. 2023 
Teacher Design Knowledge for Technology Enhanced Learning:

A framework for investigating assets and needs

Authors: Susan McKenney ${ }^{1,2}$, Yael Kali ${ }^{3}$, Lina Markauskaite ${ }^{4}$, and Joke Voogt ${ }^{5,6}$

Emails: Susan.McKenney@utwente.nl,yael.kali@gmail.com, Lina.Markauskaite@sydney.edu.au, j.m.voogt@utwente.nl

Affiliations: ${ }^{1}$ Open University of the Netherlands, ${ }^{2}$ University of Twente ${ }^{3}$ University of Haifa, ${ }^{4}$ University of Sydney, ${ }^{5}$ University of Amsterdam, ${ }^{6}$ Windesheim University of Applied Sciences

\section{Corresponding author contact details:}

Susan McKenney

IST/GW/UT

PO Box 217

7500AE Enschede

The Netherlands

susan.mckenney@utwente.nl

Tel: +31 534892890

Fax: not available

This is a pre-print of:

McKenney, S., Kali, Y., Mauriskite, L. \& Voogt, J. (in press). Teacher design knowledge for technology enhanced learning: An ecological framework for investigating assets and needs. Instructional Science. 


\title{
Teacher Design Knowledge for Technology Enhanced Learning:
} An ecological framework for investigating assets and needs

\begin{abstract}
Despite the fact that teaching is increasingly referred to as a design science, teacher education programs devote relatively little time to developing expertise in the design of instruction, beyond lesson planning. Yet today's teachers not only plan lessons that incorporate existing classroom activities and instructional resources, they also design new learning activities and create their own (technology enhanced) learning materials. Different approaches have been tried to support pre- and in-service teacher design learning. Past efforts to develop teacher skills in design had limited success, probably due to poor alignment of traditional instructional design models with teachers' knowledge, needs and natural ways of engaging with design tasks. More recently, researchers have begun to investigate and develop ways to build on teacher expertise to support them in their design efforts. Yet to date, little has been done to capitalize on what is already understood about teachers as designers nor to draw on the wealth of literature on designers and designing outside the field of education. With the ultimate aim of supporting the work of teachers as designers of technology enhanced learning, this contribution synthesizes research on design from classical design fields, instructional design, and teachers' designing. These perspectives are brought together in an ecological framework that can be used by researchers to study teacher design knowledge and work across projects. This synthesis could also provide an articulated framework for developers and facilitators of teacher professional development programs for identifying key areas for support to teacher-designers in specific settings.
\end{abstract}

\section{Introduction}

This special issue and especially its introduction (Kali, McKenney \& Sagy, this issue) attest to the critical importance of teachers as designers. Recently, experts have advocated the provocative notion that teaching can (and possibly should) be viewed as a design science (Laurillard, 2012). However, teacher education programs in most countries devote relatively little time to developing instructional design expertise beyond lesson planning. As a result, most teachers develop these skills intuitively through experience. This professional growth is largely influenced by the colleagues and contexts in which teachers work (Shamir-Inbal, Kali, \& Dayan, 2009), and frameworks for developing support of this work are severely lacking.

The time has come for devoting explicit attention to developing robust, empirically- and theoretically-informed support for teachers as designers. Not only is there a need in the field, but increasingly, a knowledge base is being developed that can inform such support. This includes, for example, research on: concerns voiced by teachers as they design (Boschman, McKenney \& Voogt, 2014); the powerful role of context and intuition (Kali, Goodyear, \& Markauskaite, 2011); and epistemic capacities that pre- and inservice teachers draw upon during design (Damşa et al., 2010). There are also increasing research and development efforts to study how teachers learn through the process of designing (see also Voogt et al., this issue). While common dimensions appear to be present among many studies, differing vocabularies and theoretical orientations hinder broader understanding and development of this promising avenue. This contribution speaks to the call for developing a language to frame and discuss teacher design work (Laurillard, 2012). Indeed, conceptual infrastructure is necessary to understand how teachers think (Horn, 2010) and how designers reason (Nelson \& Stolterman, 2012). To do so, this paper brings together existing research on design across disciplines, including engineering, architecture and professional instructional design, with literature on teachers as designers and how to support such teachers.

Different approaches have been employed to support the ongoing design learning of teachers. Past efforts, frequently stemming from the field of instructional design, aimed to steer teacher design toward more systematic approaches, often with promising results (Hoogveld, Paas, Jochems \& van Merrienboer, 2001; Hoogveld, Paas \& Jochems, 2005). However, specific instructional design strategies rarely became engrained in common practice, probably because these efforts were insufficiently aligned with the ways teachers intuitively approach design challenges (cf. Kerr, 1981; Kali, Goodyear, Markauskaite, 2011). More recently, researchers have begun to develop ways to build teacher design expertise (e.g. Koehler, Mishra \& Yahya, 2007). Outside the field of instructional design, interest in knowledge about design is also evident (Nelson \& Stolterman, 2012). Interest in design processes that promote creative thinking alongside analytical thinking are gaining momentum in the field of education (e.g. Razzouk, \& Shute, 2012; Design Thinking for Educators, 2013). The current contribution stems from the need to synthesize research that examines teacher design for actual use (that is, preparatory to classroom enactment) together with established knowledge and habits of mind consistent with contemporary design approaches. The aim of this paper is 
to provide an ecological framework that would support researchers in the study of teachers' design, as well as to guide development and facilitation of professional programs for teachers as designers.

After discussing the contexts in which teachers design, the body of this paper identifies and synthesizes existing insights concerning the knowledge needed to productively engage in design. We use the term knowledge broadly to refer to teachers' tacit and explicit aspects of knowing that underpin their capacity to engage skillfully in design work across situations and contexts, including capacity to learn to design in new unfamiliar situations. This includes kinds of knowledge that are often referred to as "know what," "know how," "know why," and "know when/where/who" (Lundwall \& Johnson, 1994). These underlie the mental resources that educated people draw upon to 'know with' when they perceive, think, judge and interpret an encountered situation (Broudy, 1977). Together, these kinds of knowledge underpin what Branford and Schwartz (1999, p. 70) called, "knowledge that transfers" - "our cumulative set of knowledge and experiences that we use as resources to perceive, interpret and judge situations based on our past experiences." The discussion culminates in an ecological framework for teacher design of technology enhanced learning, and concludes with reflections on the framework and how it might be used.

\section{Context: Characterizing teacher design}

Teacher engagement in design is highly varied. It is initiated for different reasons, takes place in myriad contexts, and yields diverse kinds of artifacts (e.g., as described by Goodyear \& Markauskaite, 2009). Here, we use the term 'design' broadly to reflect various concurrent considerations present in any teacher's design situation:

- First, design means establishing a 'platform of ideas' (Walker, 1971) indicates what is, a vision of what ought to be, and the core principles or frameworks that will guide development to bridge the two. Research has shown that school vision on technology use (e.g. 'traditional' or 'innovative' vision) plays a determining role in this aspect of teacher design (de Koster, Kuiper \& Volman, 2012).

- Second, similar to Goodlad's (1994) technical-professional perspective on curriculum development, this definition also includes the detailed process of imagining and constructing specific artifacts (e.g. learning tasks, software, teacher guides). Three common roles teachers assume during the detailed design of technology-rich learning activities and materials include (Cviko, McKenney \& Voogt, 2014): enactors (teachers implement ready-to-use activities, making only subtle adjustments, mostly on the fly); redesigners (teachers adapt ready-to-use activities and materials for their current curriculum); or co-designers (teachers collaboratively design completely new learning activities and materials for their classes).

- $\quad$ Third, we also understand design to entail consideration of how specific creations will align with the prevailing system in which they are to be implemented (McKenney, Nieveen \& van den Akker, 2006), including congruence with stakeholder perceptions about the design (Kessels, 1999). Teachers intuitively address classroom practical concerns while designing technology-rich learning activities and materials, but are also influenced by their own existing knowledge and beliefs, as well as external priorities such as examination systems (Boschman, McKenney \& Voogt, 2014).

Across all three aspects, a blend of creative and systematic mindsets is useful (McKenney \& Reeves, 2012). Especially for meeting design objectives in light of real-world constraints, teacher imagination is a prized asset during design. At the same time, rational, systematic work is needed for achieving design coherence while carefully satisficing between ideal and feasible options. When it comes to the focus of this special issue - designing technology enhanced learning - the process teacher-designers go through is greatly influenced by their technological pedagogical content knowledge, beliefs, skills and attitudes (e.g. TPACK, Mishra \& Koehler, 2006).

Sometimes design is undertaken to learn and innovate, as is often the case when teachers engage in design research or action research. When designing is part of coursework (e.g. continuing education credit), the main driving force is teacher professional development (e.g., Sagy \& Kali, 2014). In other cases, teachers undertake curriculum design as a means to achieve school improvement (e.g., Handelzalts, 2009). There are also settings in which the dual goals of curriculum reform and professional development are sought, such as in professional development courses targeting leaders of change in schools (e.g. Svihla et al., this issue; Voogt et al., this issue). New technological opportunities embedded in the design of learning environments, can serve as a catalyst for teachers to rethink their practice, try new things and explore creative alternatives (Goodyear \& Markauskaite, 2009; Mishra, Koehler \& Zhao, 2007).

Teachers design in many different contexts, at (pre-)primary, secondary and tertiary levels of education. The design activity may be undertaken by individuals, a few colleagues, or in large teams where in some cases researchers act as co-designers (e.g., Bielaczyc, 2013). The designing teachers may create artifacts for local contexts (own use) 
and/or for additional settings (use by others). The number of designers tends to increase with the scope of design challenge. That is, learning activities for specific curricular topics, and individual lessons are quite commonly designed by individuals and small teams, whereas modules and cross-disciplinary designs are more often created by larger teams. Nieveen et al., (2013) present a detailed characterization of curriculum design tasks undertaken by teacher design teams, which illustrates the variety in: what teachers design; how teachers design; with whom teachers design; and in what context. The ecological framework we present below seeks to accommodate the rich variation of contexts in which teachers design technology enhanced learning.

\section{What does existing research tell us about knowledge teachers might need to productively engage in technology enhanced learning design?}

Over the last 45 years, various disciplines, including engineering, business and education, have witnessed an increase in research investigating design. This has yielded benefits for both research and practice (Simon, 1969/1996). It has also resulted in theoretical and practical investments into understanding and supporting design processes, design cognition, design thinking, design mindsets, design knowledge and design expertise (Cross, 2011, Eastman, 1969, Nelson \& Stolterman, 2012, Schön, 1983, 1987). Research on designers in various disciplines can be informative for thinking about teacher design activity. Furthermore, existing research has also been focused specifically on teacher design activity, such as studies of pedagogical patterns of classroom activity (DiGiano et al., 2003; Prieto et al., 2011).

Stempfle and Badke-Schaub (2002) identify three strains of research that focus on different aspects of design. Building on this work and others, we consider research that directly or indirectly helps frame (instructional) design and ultimately, the work of teacher designers. As a result, this section examines the following three strands of research on design: technical, phenomenological and realistic. Table 1 provides a brief overview of the primary emphasis and key concepts in each strand. Thereafter, the nature of each strand is described in relation to: (a) design knowledge in general; (b) instructional design; and (c) teacher design of technology enhanced learning. It is important to note that these strands are not mutually exclusive and our review does not intend to be comprehensive. However, the central emphasis in each strand is helpful for appreciating its key contributions to understanding what design knowledge is and how designers come to know. They also serve as main organizers in the ecological framework proposed thereafter.

Please insert Table 1 about here

Table 1. Research on design in three main strands

\begin{tabular}{|c|c|c|c|}
\hline Strand & Technical & Phenomenological & Realist \\
\hline $\begin{array}{l}\text { Primary } \\
\text { emphasis }\end{array}$ & $\begin{array}{l}\text { Models and frameworks to } \\
\text { guide design }\end{array}$ & $\begin{array}{l}\text { Designers' reflections on and } \\
\text { responses to the environment, } \\
\text { and their related experiences }\end{array}$ & $\begin{array}{l}\text { What designers actually do, how } \\
\text { they do it and why they do it }\end{array}$ \\
\hline $\begin{array}{l}\text { Key } \\
\text { concepts }\end{array}$ & $\begin{array}{ll}\text { - } & \text { Design thinking } \\
\text { - } & \text { Design process guidance } \\
\text { - } & \text { Criteria for well-designed } \\
& \text { products } \\
\text { - } & \text { Teacher instructional } \\
& \text { planning tools }\end{array}$ & $\begin{array}{ll}\text { - } & \text { Improvisation } \\
\text { - } & \text { Eesign schemas } \\
\text { - } & \text { Teacher intuition, awareness } \\
& \text { and experience }\end{array}$ & $\begin{array}{ll}\text { - } & \text { Designer expertise } \\
\text { - } & \text { Design cognition } \\
\text { - } & \text { Novice-expert differences } \\
\text { - } & \text { Teacher TPACK and its } \\
\text { influence on pedagogical } \\
\text { design capacity } \\
\text { - Teacher practical concerns } \\
\text { while designing }\end{array}$ \\
\hline
\end{tabular}

In this contribution, we focus on research concerning the design knowledge of individuals (even if they are working in teams). We do consider teamwork to be extremely important in teacher design, but teachers' collaborative design capacity cannot be understood without understanding individuals. We further note that teacher design teams are discussed in detail in this issue and elsewhere (e.g. Voogt et al., 2011; Voogt et al., this issue).

\subsection{The technical strand in research on design}

Dominated by design methodologists, the technical strand derives from a systematic, rational, problem-solving mindset; this strand of research features the derivation, testing and critique of models to support the process of 
design. These kinds of models have been used to educate designers in various fields (e.g. Branch \& Kopcha, 2014; Dick, Carey \& Carey, 2001; Otto \& Wood, 2001; Ulrich, Eppinger \& Goyal, 2011). Decades ago, the models might have been characterized as rather sterile - tending little to context or human values. But recent work of this sort views the design process as social, placing high value on contextual understanding and empathy while not losing sight of systematic action and reflection. For example, the Hasso-Plattner Institute of Design at Stanford University embodies these views in their trans-disciplinary program that teaches and researches a process which can be personalized, internalized and applied in a variety of settings, ranging from IT/engineering (Plattner, Meinel \& Leifer, 2010) to social innovation (Brown \& Wyatt, 2010) and education (Carroll et al., 2010). Key components of the design process models include efforts to understand, observe, take points of view, ideate, prototype and test. In addition to the process, the design thinking mindset is central to this work; it includes: human-centeredness, empathy, mindfulness of process, culture of prototyping, a "show don't tell" approach, bias toward action, and radical collaboration.

The field of education is rich with a history of technical (especially instructional) design models. McKenney and Reeves (2012) distinguish two kinds: those focusing on output and those focusing on process. The models focusing on output describe characteristics of the products of instructional design. For example, Gagne's (1985) nine events of instruction and van Merriënboer and Kirschner's (2012) four component instructional design model focus on output, because they primarily provide guidelines for shaping the products of design. By contrast, other models focus on the design and development process, such as the phases distinguished in Posner and Rudnitsky's (1994) classic text, Course Design: A guide to curriculum development for teachers. After surveying dozens of design models, Gustafson and Branch (2002) concluded that nearly all of them were shaped around the following five core components: analysis, design, development, implementation and evaluation. As in other fields, the trend to incorporate systems thinking into educational design consideration has grown in the last two decades, and more recent design models explicitly devote attention to social and implementation considerations throughout the design process (e.g. McKenney \& Reeves, 2012).

With regard to teachers as designers of technology enhanced learning, research related to the technical strand includes studies that help facilitate or model instructional planning. For example, DiGiano et. al (2003) describe a set of eight 'collaborative design patterns,' which provide teacher-friendly templates for generating high-quality collaborative learning activities that capitalize on the affordances of wireless technologies. Similarly, Harris and Hofer (2009, p. 4089), distinguish 'learning activity types,' which "function as conceptual planning tools for teachers; they comprise a methodological shorthand that can be used to both build and describe plans for standardsbased learning experiences. Each activity type captures what is most essential about the structure of a particular kind of learning action as it relates to what students do when engaged in that particular learning-related activity (e.g., group discussion; role play; fieldtrip)." For example, they identified 42 social studies activity types, and structured them through three sets of taxonomies, emphasizing knowledge building, convergent knowledge expression, and divergent knowledge expression, respectively. In a related vein, Angeli and Valanides (2009) introduce the concept of 'technology mapping' to help teachers link technology applications to specific instructional purposes; this too bears some resemblance to other pattern-based models of learning design (Goodyear, 2005; Goodyear \& Retalis, 2010; Laurillard, 2008; McAndrew, Goodyear, Dalziel, 2006).

\subsection{The phenomenological strand in research on design}

The phenomenological strand contains research focusing on designer experience and consciousness. Inquiry into and through design is not only useful for deriving knowledge about the world, but to enable us to better 'correspond' with it (Ingold, 2013). Here, correspondence refers to the strophic interaction between designers and context in which they act, where each takes turns leading and being led. While this strand does not imply any specific philosophical orientation, ontology or epistemology, it does assume that the design process is not so systematic, guided by explicit rules, or predictable. Rather, the work of design is flexible and resembles that of an artist, whose appreciation and reflections prompt the selection of techniques and actions. A prominent contributor and pioneer in this line of research is Donald Schön, with his seminal books The Reflective Practitioner (1983) and Educating the Reflective Practitioner (1987). In these works, Schön introduced the provocative idea that professionalism in various design areas, such as engineering, architecture or town planning, are not necessarily developed in normative, systematic manners. Rather, he claimed, professionalism is gained by 'reflection-in-action,' which enables the practitioner to think deeply about situations while they are happening, interpret and frame them in particular ways and adapt his/her actions accordingly. The phenomenological strand assumes that design work is both improvisational and patterned. However, the nature of the patterns in this strand is more visceral than systematic or 
rational. In their book, The Design Way (2012), Nelson and Stolterman extensively discuss the cognitive and cultural tools that organize designer thinking: 'design schemas.' In contrast to systematic or rational patterns that guide design, they argue that 'design schemas' "share the same underlying processes of subconscious judgment making that unify immensely complex inputs of information and design reasoning into singular images. The ability to create and use high-value schemas is at the heart of design scholarship..." (Nelson \& Stolterman, 2012, p. 8).

In education, the phenomenological perspective on design has roots in the1970's debates concerning the epistemological foundations of schooling. Eisner (1976) criticized the desire to create a 'science of education' that would enable prediction through controlled processes of teaching, curriculum design and evaluation. As an alternative to behaviorist, objectives-driven approaches to education, Eisner stressed the multiple, subjective, constructed ways in which people make meaning and learning processes are enacted. He advocated for 'educational connoisseurship,' a more humanistic approach to education. He viewed teaching and curriculum design as activities that require artistry (Eisner, 1976). In his approach, educators (including teachers, curriculum designers, and policymakers) develop awareness of the qualities of classroom life. Eisner $(1979,1994)$ mapped seven dimensions related to curriculum planning, and pointed out how context influences these: goals and their priorities; content; types of learning opportunities; organization of learning opportunities; organization of content areas; mode of presentation and mode of response; and types of evaluation procedures. He emphasized that his artistic approach was not comprehensive, and that the ideas he proposed were not tied to any particular sequence. Eisner's approach offers general guidelines only, leaving actual planning and decision-making in the hands of the curricular 'artist.' From his perspective, the teacher is at the forefront of the process of curriculum and instructional design, and the interests of individual students should be emphasized.

In the teachers as designers of technology enhanced learning line of research, phenomenological views are expressed by taking into account teachers' use of their intuitive knowledge for making design decisions and judging between alternatives. Such views highlight teacher awareness, subjectivities and experience, and call for refining these with reflection on the epistemologies underlying design decisions. For example, Ronen-Fuhrmann, Kali and Hoadley (2008) studied graduate level teacher-designers and found that the collaborative negotiations of design tensions (a) developed their skills to design educational-technologies; and (b) increased the coherence of their epistemological understanding of how people learn. The phenomenological perspective is in accordance with previous work on the nature of teacher learning (Putnam \& Borko 2000) and instructional planning as situated (Clark \& Dunn 1991) and contextually sensitive (Brown 1992). For example, this is the case with the work of Donald and colleagues (2009) who describe their HEART (HEaring And Realising Teaching-voice) methodology an approach to design that is intended "to help teachers and designers select and work with existing learning design by helping them reflect on and articulate the education beliefs underlying their own and others' teacher and learning design practice," (2009, p. 180).

\subsection{The realist strand in research on design}

The realist strand comprises the largest empirical research base of the three; the focus of the studies that we include in this strand is on what designers actually do, how they do it and why they do it Work related to the realist strand has especially called attention to trade-offs and complications facing designers working under typical, as opposed to ideal, conditions. Research in this area, known under labels such as 'design expertise' and 'design cognition' started in the field of architectural design in early 1970s (Cross, 2001, 2011; Eastman, 1969, 1970, 2001; Lawson \& Dorst, 2009). Later, this view was expanded in many other fields of design work, such as industrial design, mechanical engineering, software design, including instructional design (see for overviews Cross, 2001; Kerr, 1983; Kirschner, et al., 2002). Here, we briefly outline some fundamental aspects of design expertise and cognition (Cross, 2001, 2011; Eastman, 2001; Mehalik \& Schunn, 2006; Schön, 1983):

- Different from problem solving: While well-defined problem solving is often described as a search for optimal solutions, the cognitive processes involved in design work involve solution of ill-structured problems that, in best case, can be described as the search for satisficing solutions. This requires not only solution generation, but also a simultaneous process of problem framing and formulation (Cross, 2011; Mehalik \& Schunn, 2006). It can be hampered by design fixation: a powerful psychological phenomenon in which the designer cannot think of alternative solutions because one particular concrete solution is highly salient. Particularly the engineering design literature has examined a variety of techniques for overcoming fixation (Christensen \& Schunn, 2009; Linsey, Wood, \& Markman, 2008a, 2008b; Mehalik \& Schunn, 2006; Tseng, Moss, Cagan, \& Kotovsky, 2008). 
- Concurrent aspects: One of the important features of expert designers' strategies is that they work at many levels of detail in parallel (Cross, 2011).

- Thinking is externalized: Design cognition is not only an internal mental process. Sketching is the central aid that helps designers to iterate and shift between different levels and unfinished solutions- designers "think by drawing", by creating and interacting with external representations (Eastman, 2001; Cross, 2011).

- Design is personal: While formal knowledge of the problem and design is important, studies show that designers often draw on personal experiences and informal knowledge (Eastman, 2001). Personality traits such as interest and involvement, commitment, self-confidence, risk-taking and willingness to work in teams are important qualities of successful designers (Cross, 2011).

- 'A-ha moments' are the exception: Design studies demonstrate that even innovative design work involves numerous routine design decisions. Many creative ideas emerge not from a sudden insight, but from accumulation of prior generated ideas and decisions. According to Cross (2011, p. 129), design is more like building a "creative bridge" than taking a "creative leap."

Empirical studies of educational designers offer insights into design cognition, often by focusing on the differences between novice and experienced instructional designers (Kerr, 1983; Kirschner, 2002; Ertmer, et al., 2008, 2009; Rowland, 1992; see for review Kali, Goodyear, Markauskaite, 2011). In one of the first studies of beginning instructional designers, Kerr (1983) found that novices have a difficulty representing design problems; they eliminate design alternatives very quickly and do not know when to stop their design work. Kirschner et al. (2002), after reviewing a number of studies describing instructional design practices, broadly concluded that there are significant differences between beginning and experienced designers. Experienced instructional designers usually more thoroughly explore a design problem; they take into account a wider range of factors and use context knowledge to solve it; they spend more time prototyping and consider a wide range of possible solutions. While many studies focused on novice and expert differences, Visscher-Voerman and Gustafson (2004) found that even experienced instructional designers vary widely in in their design strategies and often approach design problems in individual and situation-specific ways.

Empirical studies of teachers as designers have explored teachers' design beliefs, thinking, cognition and knowledge in a variety of ways. For instance, Davis et al. (2011), drawing on Brown (2009), investigated teachers' pedagogical design capacity -- "a teacher's ability to employ personal resources as well as resources embedded in the [curriculum] materials themselves to make productive changes to curriculum materials" (p. 797). A number of studies have looked at teacher design capacity in natural settings from a technological, pedagogical, content knowledge (TPACK) perspective (Kali, Markauskaite, Goodyear, \& Ward, 2011; Koehler \& Mishra, 2005; McKenney, Voogt \& Boschman, 2015. Koehler and Mishra (2005) argued that TPACK represents what teachers need to know about technology and argued that authentic design-based activities play an important role in the development of this knowledge. In this view, teachers' design capacity, like their capacity to teach with technology, includes the ability to blend together knowledge that emerge from the intersections of content, pedagogical and technological knowledge and their interdependency with experiences and context (DiSessa, 1988; Kali, Goodyear, \& Markauskaite, 2011; Markauskaite \& Goodyear, 2014). Other studies have examined the processes teachers undertake during instructional design. For decades it has been clear that teacher approaches to design differ substantially from those described in instructional planning models: "instructors rarely start from well-defined objectives, but rather think through situations, activities, or other elements of the teaching environment" (Kerr, 1983, p. 375). Ellis, Steed, and Applebee (2006) found that university teachers' approaches to design are associated with their beliefs about the teaching of a particular subject and the role of technologies in their teaching and learning. McKenney, Voogt and Boschman (2014) found that kindergarten teachers' considerations during design were influenced most by practical concerns, but also by their pedagogical orientation, beliefs about how children learn, and convictions of how learning should be supported by teachers. Overall, the realist studies show that teachers often take a pragmatic approach toward design: prioritizing the practical use of designs and privileging feasibility, in ways that are congruent with their own beliefs and convictions.

\section{An ecological framework for conceptualizing teacher knowledge for design}

Based on the previous discussions, this section articulates an ecological framework that can be used to analyze the knowledge teachers appear to have and/or need for designing. As previously noted, we define design knowledge in the broadest sense, including different kinds of knowledge resources and aspects of knowing that enable intelligent and fluent design work by teachers across situations and contexts. We view this framework as ecological because it emphasizes complex dependencies and interactions central to design. Building on the review of literature above, the 
framework emphasizes different kinds of integrated knowledge (know-what, know-why, know-how, know-when, know-who), stemming from design across disciplines, within education and specifically pertaining to teachers as designers of technology enhanced learning. Moreover, the framework brings together and points out potential relationships between three conventionally separated strands of research on design (technical, phenomenological and realist). As a whole, the framework provides an overview of key aspects of knowledge teachers need in the different kinds of design settings described in the Context: Characterizing teacher design section. This could help researchers as well as developers and facilitators of teacher professional development programs to identify areas that require support as well as strengths upon which to capitalize. Also, if the framework would be used to structure repeated investigations, changes could be tracked over time. This has the potential to yield insights into the development of teacher knowledge for design, as well as the processes that appear to foster (or hinder) their development.

The ecological framework is presented in Table 2 and explained in detail thereafter. The columns are inspired by the three strands of research on design: powerful design heuristics is inspired by the technical strand; teacher-design consciousness and situated experience relates to the phenomenological strand; and realistic understanding of design practices stems from the realist strand. Each column contains questions that could be asked to identify assets and needs among teacher designers. The rows build on Schoenfeld's (2010) four basic aspects of decision making: the knowledge base; disciplinary habits and practices; metacognition; and productive beliefs aligned with those of the discipline. These aspects are critical throughout educational design. They are also consistent with Lundvall and Johnson's (1994) notions of the kinds of learning processes that characterize what is required by participants in modern 'learning economies' capable of continually learning and dynamically adapting to changing circumstances and demands. Specifically, we examine the following aspects of teacher design knowledge:

- know-what: teachers' fundamental knowledge base;

- know-why: teachers' productive beliefs, including articulated principles and (sometimes unarticulated) experience-based wisdom;

- know-how: teachers' repertoire for action, including intuitive (embodied in skill) knowledge;

- know-when: teachers' tacit and reflective abilities to judge which ideas and processes make the most sense under certain circumstances, at certain points in time, with certain people;

- Know-who: teachers' awareness for consulting relevant expertise; and

- Know-where: teachers' understanding of design work in the local and broader system contexts.

Please insert Table 2 about here

Table 2. An ecological framework for conceptualizing teacher knowledge for technology enhanced learning design

\begin{tabular}{|c|c|c|c|}
\hline $\begin{array}{l}\text { Inspired by } \\
\text { (research } \\
\text { strands) }\end{array}$ & $\begin{array}{l}\text { Technical } \\
\text { Models and frameworks to } \\
\text { guide design } \\
\text { - Design thinking } \\
\text { - Design process guidance } \\
\text { - Criteria for well- } \\
\text { designed products } \\
\text { - Teacher instructional } \\
\quad \text { planning tools }\end{array}$ & $\begin{array}{l}\text { Phenomenological } \\
\text { Designers' reflections on and } \\
\text { responses to the environment, } \\
\text { and their related experiences } \\
\text { - Improvisation } \\
\text { - Design schemas } \\
\text { - Educational } \\
\text { connoisseurship } \\
\text { Teacher intuition, } \\
\text { awareness and experience }\end{array}$ & $\begin{array}{l}\text { Realist } \\
\text { What designers actually do, } \\
\text { how they do it and why they } \\
\text { do it } \\
\text { - Designer expertise } \\
\text { - Design cognition } \\
\text { - Novice-expert differences } \\
\text { - Teacher TPACK and its } \\
\text { influence on pedagogical } \\
\text { design capacity } \\
\text { - Teacher practical } \\
\text { concerns while designing }\end{array}$ \\
\hline $\begin{array}{l}\text { Aspects of } \\
\text { teacher } \\
\text { transferable } \\
\text { knowledge }\end{array}$ & Powerful design heuristics & $\begin{array}{l}\text { Teacher-designer } \\
\text { consciousness and situated } \\
\text { experience }\end{array}$ & $\begin{array}{l}\text { Realistic understanding of } \\
\text { design practices }\end{array}$ \\
\hline
\end{tabular}




\begin{tabular}{|c|c|c|c|}
\hline $\begin{array}{l}\text { Know-what } \\
\text { (fundamental } \\
\text { knowledge base) }\end{array}$ & $\begin{array}{l}\text { What do teachers know about } \\
\text { design thinking and which } \\
\text { design models are likely to } \\
\text { be most useful for them in a } \\
\text { given situation? }\end{array}$ & $\begin{array}{l}\text { What intuitive knowledge, } \\
\text { awareness and experiences do } \\
\text { teachers bring with them to } \\
\text { design technology enhanced } \\
\text { learning? }\end{array}$ & $\begin{array}{l}\text { What knowledge do teachers } \\
\text { really use when designing } \\
\text { technology enhanced } \\
\text { learning and what issues do } \\
\text { they typically overlook? }\end{array}$ \\
\hline $\begin{array}{l}\text { Know-why } \\
\text { (productive } \\
\text { beliefs) }\end{array}$ & $\begin{array}{l}\text { In what ways do teachers } \\
\text { know why careful attention } \\
\text { to shaping design processes } \\
\text { (before and during } \\
\text { enactment) is critical for } \\
\text { successful outcomes? }\end{array}$ & $\begin{array}{l}\text { In reflecting on their own } \\
\text { design decision-making, to } \\
\text { what extent do teachers know } \\
\text { why they make specific choices } \\
\text { in certain situations? }\end{array}$ & $\begin{array}{l}\text { What productive beliefs } \\
(\text { know-why) underpin design } \\
\text { decisions that } \\
\text { teachers really make } \\
\text { and how do they change with } \\
\text { experience? }\end{array}$ \\
\hline $\begin{array}{l}\text { Know-how } \\
\text { (repertoire for } \\
\text { action) }\end{array}$ & $\begin{array}{l}\text { What do teachers know } \\
\text { about how healthy design } \\
\text { processes proceed? (and how } \\
\text { similar or different they are } \\
\text { from the natural design } \\
\text { inclinations of teachers) }\end{array}$ & $\begin{array}{l}\text { What do teachers know about } \\
\text { how their own design schemas } \\
\text { develop? (and how this relates } \\
\text { to their own intuitive } \\
\text { knowledge) }\end{array}$ & $\begin{array}{l}\text { What TPACK (know-how) } \\
\text { do teachers really have and } \\
\text { use during design? (and how } \\
\text { does this influence } \\
\text { their overall pedagogical } \\
\text { design capacity) }\end{array}$ \\
\hline $\begin{array}{l}\text { Know-when } \\
\text { (judgment of } \\
\text { ideas and } \\
\text { processes in } \\
\text { various } \\
\text { contexts) }\end{array}$ & $\begin{array}{l}\text { How well do teachers know } \\
\text { when they should choose, re- } \\
\text { assess or change a particular } \\
\text { approach to guide the design } \\
\text { process? }\end{array}$ & $\begin{array}{l}\text { How well do teachers know } \\
\text { when to improvise and when } \\
\text { are one's own ideas put to use, } \\
\text { given the setting and goals? }\end{array}$ & $\begin{array}{l}\text { What are realistic decisions } \\
\text { teachers make in various } \\
\text { contexts (know-when) and to } \\
\text { what extent are these } \\
\text { decisions based on tacit } \\
\text { (rather than reflective) } \\
\text { knowledge, or some other } \\
\text { design expertise? }\end{array}$ \\
\hline $\begin{array}{l}\text { Know-who } \\
\text { (awareness for } \\
\text { consulting } \\
\text { relevant } \\
\text { expertise) }\end{array}$ & $\begin{array}{l}\text { How well do teachers know } \\
\text { who they should consult for } \\
\text { guidance on design } \\
\text { processes and/or the } \\
\text { products of design in certain } \\
\text { contexts? }\end{array}$ & $\begin{array}{l}\text { How well do teachers know } \\
\text { who might enrich and inspire } \\
\text { their awareness or educational } \\
\text { connoisseurship? }\end{array}$ & $\begin{array}{l}\text { How well do teachers really } \\
\text { know who they can consult } \\
\text { with during different stages } \\
\text { of design work and for which } \\
\text { main purposes? }\end{array}$ \\
\hline $\begin{array}{l}\text { Know-where } \\
\text { (understanding } \\
\text { design work in } \\
\text { context) }\end{array}$ & $\begin{array}{l}\text { How well do teachers know } \\
\text { where locally relevant } \\
\text { policies, models and } \\
\text { frameworks to inform design } \\
\text { are already present in their } \\
\text { own environments? }\end{array}$ & $\begin{array}{l}\text { How well do teachers know } \\
\text { where influences of colleagues, } \\
\text { leaders and policies can be } \\
\text { found in their own ideas, } \\
\text { values and goals that shape } \\
\text { design? }\end{array}$ & $\begin{array}{l}\text { How well do teachers really } \\
\text { know where - in the } \\
\text { curriculum, the classroom or } \\
\text { the school - design work } \\
\text { tends to thrive or struggle? }\end{array}$ \\
\hline
\end{tabular}

\subsection{Powerful design heuristics}

This strand in the framework emphasizes design as a disciplinary knowledge and skill. From this perspective, design can be seen as a distinct domain of disciplinary expertise (Simon, 1969/1996). Thus, as all disciplines, it should organize its disciplinary knowledge base using certain formal conceptual structures and use certain explicit procedures for producing new knowledge products and verifying claims (Nelson \& Stolterman, 2012; Schwab, 1962). This formal knowledge can be learned deliberately and deployed in practice. From this perspective, teacher design expertise should be underpinned by a certain formal body of knowledge and systematic ways of knowing that represent the conceptual basis of the design discipline, such as design languages, principles, patterns and frameworks (Laurillard, 2012). 
Knowledge of powerful design heuristics can increase the efficiency and effectiveness of teachers' design work. This draws on the technical strand of research and is based on the notion that knowledge of principles and processes (as portrayed through models and frameworks) can help designers skillfully structure their work (know-what). Huizinga et al. (2013) investigated this when examining the design process expertise teachers need when creating new curricula. Effective teacher design is fed not only through an understanding of procedures or conceptual tools, but also the understanding of why they are valuable under certain conditions (know-why). These are pre-requisites for teachers to being able to use them well (know-how). Healthy design processes blend planned rationality with sensitivity to human concerns; this points to the importance of empathy and interpersonal skills for teachers to facilitate design. Communication across expert groups is notoriously challenging, particularly when it comes to the design of technology enhanced learning, in which different kinds of expertise may be needed. For example, the CASCADE-MUCH study (Wang, Nieveen \& van den Akker, 2007) specifically investigated how to support teachers in communicating their multimedia scenario designs to software developers, using 'storyboarded blueprints.' Having the knowledge to critically assess process in a timely fashion (know-when) is important for judging if: a particular approach is being (un)helpful; opportunities should be capitalized on; focus is shifting; or the current course needs to be re-evaluated. While known to be important, research has shown that teachers' intuitive approaches to design rarely include process monitoring (Boschman, McKenney \& Voogt, 2014). Especially when designing activities and resources for use by others, consulting relevant expertise (know-who) can provide valuable guidance on either design processes or the resulting products. Finally, to align new designs with the target context (McKenney, Nieveen \& van den Akker, 2006), it is helpful for teachers to be aware of and incorporate existing policies, models and frameworks that are already present within the local and/or system environment (know-where).

\subsection{Designer consciousness and experience in the environment}

This strand in the framework relates to theories of situated cognition, which view design work and ways of knowing as deeply embedded in situated activities, contexts and culture (cf. Cook \& Brown, 1999; Lave \& Wenger, 1991). From this perspective, designerly ways of knowing are learned through direct and indirect engagement in authentic design practices, rather than an explicit, formally-represented body of knowledge and skills (Schön, 1983).

Likewise, design expertise is underpinned by tacit knowledge and skills that, while learned through engagement in shared practices, remain largely individual and unarticulated. Thus, much relevant teacher design expertise is an intuitive capacity that is acquired through every day, mostly invisible, work that forms a natural part of authentic teaching practice.

A designer's own consciousness and experience in the environment is necessary for developing intuition, habits of mind and routines that can serve future work. Drawing on the phenomenological strand, this knowledge recognizes that personal, situated experiences offer rich resources for improvisation and connoissership. This includes an understanding of the intuitive knowledge, awareness and experiences (know-what) that teachers bring with them, and the fact that teachers draw on these to design technology enhanced learning (Kali \& Ronen-Fuhrmann, 2011), which oftentimes results in productive designs (Laurillard, 2012). The difficulty to articulate a design rationale (lack of know-why), as is often the case with novice teacher designers, can limit the quality of the design work (Kali \& Ronen-Fuhrmann, 2011). Frequently, when they are asked to reflect on their designed solutions, teachers seem to have limited language to do so (Voogt et al., 2013a). This could hamper the development of design schemas and even intuitive understanding of design processes (know-how). Within specific settings, a teacher's individual sense of intuition and personal experiences influence both the confidence and ability to improvise (know-when). Confidence can be inspired and abilities can be enriched when teachers know to consult relevant expertise (knowwho), as well as where the influences of colleagues, leaders and policies influence their own ideas, goals and values (know where).

\subsection{Realistic understanding of design practices}

This strand in the framework draws on what is known about designer expertise, cognition, learning and decision making. It is based on the premise that design expertise is represented by a set of social and cognitive capacities. Social capacities include engaging in shared social practices, distributing roles, planning, negotiating, sharing design tools, sketching and participating in other kinds of designerly discourse (e.g., Damşa et al, 2010). Cognitive capacities include reasoning, mental imagery, mental mapping and other kinds of information processing. This thinking is underpinned in internal memory representations and operations that allow one to think in designerly ways and perform design work (e.g., Eastman, 2001). From this perspective, teacher design practices are shaped by social capacities (e.g. teamwork, communication skills), memory representations (e.g., TPACK, pedagogical design) and cognitive operations, such as switching between and blending different mental frames, integrating abstract 
thinking about general pedagogical principles and concrete thinking about technological artifacts, settings and situational constraints (Goodyear \& Markauskaite, 2009; Markauskaite \& Goodyear, 2014).

Drawing on the realist strand, a realistic understanding of design practices helps anticipate and accommodate what is likely to happen when teachers design technology enhanced learning. By taking into account what teachers intuitively consider when designing and which pertinent issues are typically overlooked by them (know-what), it is possible to build on their strengths and preempt potential lacunas. Understanding how well teachers are aware of the reasons for their focus on certain kinds of considerations as well as if/how these change with experience (knowwhy), helps develop teacher design scenarios that explicitly address, and are not cleansed of, teacher concerns. Understanding teachers' knowledge regarding how they apply their expertise in design (know-how) enables them and others to identify opportunities for using and/or developing TPACK (Koehler \& Mishra, 2005; Koehler, Mishra \& Yahya, 2007); pedagogical design capacity (Brown, 2009; Davis et al, 2011); or design tools (Masterman, Jameson \& Walker, 2009). A realistic understanding of when teachers use tacit, as opposed to reflective knowledge (know-when) is crucial to providing relevant and usable support to teachers during decision making, as the later kind of knowledge plays central role in teachers' decisions about suitability of available learning resources and how to redesign and integrate them into their teaching (Markauskaite \& Goodyear, 2014). Recognizing these moments in which teachers make reflective knowledge is also helpful for teacher-designer development, as it affords opportunities to unpacking decision making and consulting relevant expertise (know-who). This can apply to initial design, but also to redesign, as research has shown that teachers use their personal experiences as well as experiences with unsuccessful task designs to identify design faults and inform redesign (Goodyear \& Markauskaite, 2009; Markauskaite \& Goodyear, 2014). Finally, teachers' realistic expectations about where - in the curriculum, the classroom or the school - their design work is likely to thrive or struggle (know-where) can enable teachers to work within the 'zone of proximal implementation' (McKenney, 2013).

\subsection{Applying the ecological framework: The case of teachers as design researchers}

As mentioned, the above ecological framework has been developed for researchers, developers, and facilitators of teachers-as-designers professional development programs. To illustrate how the framework might be used by such an audience, we use the framework to characterize a specific in-service teacher professional development program that one of the authors of this paper was involved in designing and enacting. The Teachers as Design-Researchers (TaDR) project (Sagy \& Kali, 2014; see also Svihla et al., this issue), is a three-semester long program that involves teachers in: the design and development of technology enhanced learning environments in each of their disciplinary area of expertise (first semester); and a small scale design study in which they explore the learning afforded by the environment (the enactment takes place in the second semester and evaluation in the third). This program has been enacted for several years, and refinements were made based on research and informal reflection on practice.

A retrospective characterization indicates that, although many of the know-what, why, how, when, who and where questions in the three strands of the ecological framework were addressed in the TaDR program, initial versions overlooked some of these cells in Table 2. As a result, preliminary enactments of many learning environments eventually designed by the teachers were of high quality with regard to the use of technology, especially for promoting collaborative inquiry (which was a pedagogy specifically emphasized), but lacked capacity to promote students' deep understanding of content. In further enactments, teachers' consultations with educational researchers who were also content experts were added to the already existing opportunities to learn from their peers and from the expert design knowledge of instructors.

It seems that the ecological framework could have been useful in assisting the TaDR designers to identify that more emphasis should have been made to promote the 'know-how' in the 'realistic understanding of design practices' strand (addressing the question 'what TPACK (know-how) do teachers really have and use during design?') and on the 'know-who' in the 'powerful design heuristics' strand (addressing the question 'how well do teachers know who they should consult for guidance on design processes and/or the products of design in certain contexts?'). This retrospective description of the TaDR program using the ecological framework illustrates how it can assist not only in mapping such practice in light of the rich literature regarding design and design education, but also in identifying the alternative ways to supporting specific aspects of teacher design practice.

\section{Discussion}

This paper set out to develop conceptual infrastructure that could help frame and discuss teacher design work. First, attention was given to characterizing the uniqueness of teacher design work (as compared with expert design work). 
Next, three strands of existing research on design were discussed in light of their contributions across disciplines, within education, and specifically pertaining to teachers as designers of technology enhanced learning; these were the technical, phenomenological and realist strands. Then, key concepts from each field and strand were integrated in an ecological framework for conceptualizing teacher knowledge in the context of designing technology enhanced learning. After discussion of the framework, a brief example was given of how it could be used. The current section considers how tacit knowledge, creativity, teacher design expertise and concurrent design considerations relate to the framework and gives recommendations for future research, before offering closing considerations.

\subsection{Tacit knowledge}

As the ecological framework demonstrates, teachers' design work, at least in part, draws on some kinds of formal heuristic knowledge and situated performance, and requires one's cognitive capacity and social skill to engage in certain kinds of epistemic work. From this perspective, designerly ways of thinking could be best understood as an epistemic practice firmly grounded in an assemblage of distinctive kinds of intellectual and material work: “...the amalgam of places, bodies, voices, skills, practices, technical devices, theories, social strategies and collective work, that together constitutes techno-scientific knowledge practices" (Turnbull, 2000, p. 44). This assemblage draws on distinct kinds of insights (know-what, know-how, know-why, know-when, know-who and know-where), many of which are tacit. Based on a rich history of metacognitive research on children's strategy choice (Shrager \& Siegler, 1998), more recent research involving experts has shown that strategy choice is governed by implicit learning and memory more than by awareness (Reder \& Schunn, 1996). But little research has been conducted to explore teacherdesigner tacit knowledge during design. Research is needed to better inform relevant aspects in the framework, including: Why are teachers more and less aware of their own decision-making rationales in certain situations? (teacher-designer consciousness); and What are realistic decisions teachers make in various context (know-when) and to what extent are these decisions based on tacit (rather than reflective) knowledge, or some other design expertise? (realistic understanding of design practices).

\subsection{Creativity}

Creativity relates to each main strand in the ecological framework. Powerful design heuristics contain guidance to facilitate ideation and nourish the creative spirit. Creativity is required for teachers to consciously employ 'disciplined improvisation' in the classroom (Sawyer, 2006) and to design resources accordingly. Realistic understanding of design practices includes knowledge of how creativity is and can be stimulated among teachers and designers. Realistic understanding can then be used to inform powerful design heuristics in the ideation stage, e.g. by emphasizing the value of verbalization over sketching during ideation (Jonson, 2005), focusing on far-field, lesscommon examples to stimulate use of analogical design reasoning (Chan, et al., 2011). Powerful design heuristics can also take into account the consciousness and situated experiences embedded in teacher-designer creative engagement, as is the case with the participatory design approaches described in Design Things (Binder et al., 2011) and How Teachers Contribute to Designs of Technology Enhanced Learning (Cober, Tan, Slotta, So \& Könings, this issue). Confirming Schön's work (1983), Dorst and Cross (2001) showed that identifying surprises helps designers stay creative even in light of routine tasks, because it prompts framing and reframing of the problem. Further research is needed to describe, explain and predict teacher-designer creativity as well as to develop effective, efficient and enjoyable mechanisms to enrich it.

\subsection{Teacher design expertise}

Important for several reasons, framing and reframing design tasks includes those that are novel and those that are routine. A novel design task is a totally new endeavor, such as the creation of an innovative lesson series that uses inquiry learning to foster deep understanding of diffusion and osmosis. In contrast, routine design tasks represent additional instances of tasks previously undertaken, such the creation of a second innovative lesson series using inquiry learning but this time for Mendelian inheritance. The distinction in task types seems important, because recent scholarship has uncovered and emphasized key differences in expertise, particularly routine expertise and adaptive expertise (Lin, Schwartz \& Bransford, 2007; Bransford, et. al, 2010). Whereas predictably similar situations require routine expertise, novel situations require adaptive expertise.

Because novel and adaptive expertise develop differently, it is important to understand the commensurate differences in the design tasks undertaken by teachers in order to provide adequate opportunities for development and support. Research has shown that teachers require support when designing novel, but also routine tasks (Huizinga, et al., 2013). When it comes to designing technology enhanced learning, additional issues bear consideration. For example, teacher interest, confidence, motivation and self-efficacy for working with technology 
influence the overall process (Christensen \& Knezek, 2009; Ertmer, 2005; Ertmer \& Ottenbreit-Leftwich, 2010; Voogt, et al., 2013b) and are known to vary highly.

Further research is needed to gain improved realistic understanding of teacher design practices that require adaptive and routine expertise, respectively (e.g. relating to the issue described above: What are realistic decisions teachers make in various context (know-when) and to what extent are these decisions based on tacit (rather than reflective) knowledge, or some other design expertise?). Here, investigation into expert approaches given novel and routine design challenges could be especially informative. Further, comparisons of novice approaches with those of experts could help begin to describe the learning trajectories of teacher-designers as their expertise develops. This in turn, would inform the work of those wishing to support teacher designers. Especially when it comes to studying the development of designer expertise, we can continue to learn from the extensive work on design education across multiple disciplines, for example by replication of study approaches that have been conducted previously in other fields, but now focusing on teachers as designers of technology enhanced learning.

\subsection{Concurrent design considerations}

In Context: Characterizing teacher design, we described several concurrent considerations present in any teachers' design situation. These considerations align well with descriptions in literature (and especially the three aspects of educational design described by Burkhardt [2009]). Here, we revisit each consideration in light of the ecological framework. The first consideration pertained to the foundations of design work, such as determining core design principles, learning progressions, or connections within and across learning sequences. While pre-service teachers do learn about the alignment of objectives, activities and assessment in lesson planning, teachers rarely have opportunities to further develop expertise required for establishing the broader foundations of design work. The second consideration is the detailed processes of imagining and constructing specific resources. This is perhaps the most familiar to teachers, because it is closest to lesson planning. The third consideration is how the designed product relates to the broader system in which it will be used. This includes (McKenney \& Reeves, 2012): understanding and accommodating real-world constraints; distinguishing early between the changeable and nonchangeable factors within a design situation and tailoring the design accordingly; and enactment of implementation strategies based on a plausible theory of change. While this third consideration seems less pertinent when designing for personal use, it is essential for actual uptake and sustained use of designs intended for others.

Scholarship is needed to better understand how teacher-designers perceive, tackle and conquer these challenges, by seeking answers to questions like: What approaches would help teachers align foundations of design work, characteristics of specific resources, and implementation in the class/school/district/state system? (powerful design heuristics); How do teachers develop awareness of the relationships between design foundations, specific designed resources and the broader system in which they are used? (teacher-designer consciousness and situated experience); and When do teachers use their TPACK to establish foundations for design work, make specific design choices and/or connect designs to the prevailing system? (realistic understanding of design practices). Here too, the study of novices and especially experts could be especially useful in bringing out synergies across strands. For example, empirical descriptions of how skilled teacher-designers work would likely have implications for how the teacher design process is structured and how the quality of the designed products is judged (e.g. alignment to concurrent considerations, aesthetic criteria in each).

Especially for tackling concurrent design considerations of teacher-designers, emerging work in participatory design related to each to the three strands in the framework may provide useful springboards. For example, the notion of 'infrastructuring' is quite relevant to considering how designed products relate to the broader system. From this perspective, infrastructures should be built "by establishing working local solutions supporting local practices which subsequently are linked together, rather than by defining universal standards and subsequently implementing them" (Ciborra and Hanseth 1998, p. 315). Star \& Ruhleder (1996) introduced this concept based on their realistic understanding derived from analysis of a large-scale custom software effort in which a collaborative system was designed for a geographically dispersed community of geneticists. Building on this work, Pipek and Wulf (2009) developed a framework that provides methodological support for infrastructuring during design. And while case studies on 'infrastructuring and the formation of publics' touch on varied aspects, these include the consciousness and situated experiences of the co-designers: "As the group came to realize its capabilities and limitations (in technical skills, knowledge of municipal regulations, and radio content development), it reached out to external groups and individuals with expertise in these domains," (Le Dantec \& DiSalvo, 2013, p. 254). Similarly, participatory design and its exploration of the roles of unusual suspects in design decision making could be 
informative. This includes, for example, 'agonistic public spaces' as opposed to consensual decision-making trajectories (Björgvinsson, Ehn, \& Hillgren, 2010, 2012); and integration of student, teacher and designer perspectives in the design of learning (e.g. Instructional Science Special Issue, 2014).

\subsection{Conclusion}

This contribution reviewed and synthesized key concepts from literature on design into a framework representing the ecology of teacher design knowledge. We describe it as ecological to emphasize interactions between elements. This includes relationships between the different kinds of knowledge described: know-what, know-why, know-how, know-when, know-who. It also includes synergies across conventionally separated strands of research on teacher design, namely those: yielding powerful design heuristics, emphasizing teacher-designer consciousness and situated experience, and generating realistic understanding of design practices. With the aim of supporting new research and development initiatives, the ecological framework is intended to help investigate teacher design in the context of technology enhanced learning. Such work can serve fundamental understanding regarding how teachers design, which is essential as a basis for developing support for the process. Used repeatedly, the ecological framework can also serve individual project development, as well as cross-project fertilization and comparison. Building on this framework, future work could, for example, distill realistic design heuristics that explicitly attend to teacherdesigner consciousness of their own experiences. We consider this ecological framework as a modest but important contribution to studying and supporting teachers as designers of technology enhanced learning.

\section{Acknowledgements}

The authors wish to express their gratitude to the other authors of this special issue who commented on initial ideas for this manuscript, as well as to the anonymous reviewers who provided extensive constructive feedback on earlier drafts. 


\section{References}

Angeli, C., \& Valanides, N. (2009). Epistemological and methodological issues for the conceptualization, development, and assessment of ICT-TPCK: Advances in technological pedagogical content knowledge (TPCK). Computers \& Education, 52, 154-168.

Bielaczyc, K. (2013). Informing design research: Learning from teachers' designs of social infrastructure. Journal of the Learning Sciences, 22(2), 258-311. doi: 10.1080/10508406.2012.691925.

Binder, T., Ehn, P., De Michelis, G., Jacucci, G., Linde, G., \& Wagner, I. (2011). Design things. Cambridge, MA: MIT Press.

Björgvinsson, E., Ehn, P., \& Hillgren, P.A. (2010). Participatory design and democratizing innovation. Proceedings of the 11th Biennial Participatory Design Conference (pp. 41-50). ACM.

Björgvinsson, E., Ehn, P., \& Hillgren, P.A. (2012). Agonistic participatory design: Working with marginalised social movements. CoDesign, 8(2-3), 127-144.

Boschman, F., McKenney, S., \& Voogt, J. (2014). Understanding decision-making in teachers' curriculum design approaches. Educational Technology Research and Development, 62, 393-416.

Boschman, F., McKenney, S., \& Voogt, J. (2015). Exploring teachers' use of TPACK in design talk: The collaborative design of technology-rich early literacy activities. Computers \& Education, 82, $250-262$.

Branch, R. M., \& Kopcha, T. J. (2014). Instructional design models. In Handbook of research on educational communications and technology (pp. 77-87). New York, NY: Springer.

Bransford, J. D., \& Schwartz, D. L. (1999). Chapter 3: Rethinking transfer: A simple proposal with multiple implications. Review of Research in Education, 24(1), 61-100. doi: 10.3102/0091732x024001061.

Bransford, J., Mosberg, S., Copland, M., Honig, M., Nelson, H., Gawel, D., \& Vye, N. (2010). Adaptive people and adaptive systems: Issues of learning and design. In A. Hargreaves, A. Lieberman, M. Fullan \& D. Hopkins (Eds.), Second international handbook of educational change ( pp. 825-856). London: Springer.

Broudy, H. S. (1977). Types of knowledge and purposes of education. In R. C. Anderson, R. J. Spiro, \& W. E. Montague (Eds.), Schooling and the acquisition of knowledge (pp. 1-17). Hillsdale, NJ: Erlbaum.

Brown, A. L. (1992). Design experiments: Theoretical and methodological challenges in creating complex interventions in classroom settings. The Journal of the Learning Sciences, 2(2), 141-178.

Brown, M. (2009). The teacher-tool relationship: Theorizing the design and use of curriculum materials. In J.T. Remillard, B. Herbel-Eisenman, \& G. Lloyd (Eds.), Mathematics teachers at work: Connecting curriculum materials and classroom instruction (pp. 17-36). New York, NY: Routledge.

Brown, T., \& Wyatt, J. (2010). Design thinking for social innovation. Stanford Social Innovation Review, 8(1), 3035 .

Burkhardt, H. (2009). On strategic design. Educational Designer, 1(3). Retrieved from: http://www.educationaldesigner.org/ed/volume1/issue3/article9. Accessed 12 December 2014.

Carroll, M., Goldman, S., Britos, L., Koh, J., Royalty, A., \& Hornstein, M. (2010). Destination, imagination and the fires within: Design thinking in a middle school classroom. International Journal of Art \& Design Education, 29(1), 37-53.

Chan, J., Fu, K., Schunn, C., Cagan, J., Wood, K., \& Kotovsky, K. (2011). On the benefits and pitfalls of analogies for innovative design: Ideation performance based on analogical distance, commonness, and modality of examples. Journal of Mechanical Design, 133(8), 081004. doi:10.1115/1.4004396.

Christensen, R. \& Knezek, G. (2009). Construct validity for the teachers' attitudes toward computers questionnaire. Journal of Computing in Teacher Education, 25(4), 143-155.

Ciborra, C. U., \& Hanseth, O. (1998). From tool to: Agendas for managing the information infrastructure. Information Technology \& People, 11(4), 305-327.

Clark, C. M., \& Dunn, S. (1991). Second-generation research on teacher planning. In H. C. Waxman, \& H. J. Walberg (Eds.), Effective teaching: Current research (pp. 183-201). Berkeley, CA: McCuthan.

Cook, S. D., \& Brown, J. S. (1999). Bridging epistemologies: The generative dance between organizational knowledge and organizational knowing. Organization science, 10(4), 381-400.

Cross, N. (2001). Chapter 5: Design cognition: Results from protocol and other empirical studies of design activity. In C. M. Eastman, W. M. McCracken, \& W. C. Newstetter (Eds.), Design knowing and learning: Cognition in design education (pp. 79-103). Oxford: Elsevier Science.

Cross, N. (2011). Design thinking: Understanding how designers think and work. Oxford: Berg.

Cviko, A., McKenney, S., \& Voogt, J. (2014). Teacher roles in designing technology-rich learning activities for early literacy: A cross-case analysis. Computers \& Education, 72, 68-79. 
Damşa, C., Kirschner, P. A., Andriessen, J. E. B., Erkens, G. \& Sins, P. H. M., (2010). Shared epistemic agency: An empirical study of an emergent construct. Journal of the Learning Sciences, 19(2), 143-186. doi:10.1080/10508401003708381.

Davis, E. A., Beyer, C., Forbes, C. T., \& Stevens, S. (2011). Understanding pedagogical design capacity through teachers' narratives. Teaching and Teacher Education, 27(4), 797-810.

de Koster, S., Kuiper, E., \& Volman, M (2012). Concept-guided development of ICT use in 'traditional' and 'innovative' primary schools: What types of ICT use do schools develop? Journal of Computer Assisted Learning, 28 (5), 454-464.

Design thinking for educators (2013). Retrieved from http://designthinkingforeducators.com. Accessed 12 December 2014.

Dick, W., Carey, L., \& Carey, J. O. (2001). The systematic design of instruction (5th ed.). New York: AddisonWesley Educational Publishers.

DiGiano, C., Yarnall, L., Patton, C., Roschelle, J., Tatar, D., \& Manley, M. (2003). Conceptual tools for planning for the wireless classroom. Journal of Computer Assisted Learning, 19(3), 284-297.

DiSessa, A. (1988). Knowledge in pieces. In G. Forman, \& P. Pufall (Eds.), Constructivism in the computer age (pp. 49-70). Hillsdale, NJ: Erlbaum.

Donald, C., Blake, A., Girault, I., Datt, A., \& Ramsay, E. (2009). Approaches to learning design: Past the head and the hands to the HEART of the matter. Distance Education, 30(2), 179-199.

Dorst, K., \& Cross, N. (2001). Creativity in the design process: Co-evolution of problem-solution. Design Studies, $22(5), 425-437$.

Eastman, C. M. (1969). Cognitive processes and ill-defined problems: A case study from design. In Proceedings of the International Joint Conference on Artificial Intelligence: IJCAI (Vol. 69, pp. 669-690). Washington, DC.

Eastman, C. M. (1970). On the analysis of intuitive design processes. In Moore. G, (Ed.), Emerging methods in environmental design and planning (pp. 21-37). Cambridge, MA: MIT Press.

Eastman, C. M. (2001). New directions in design cognition: studies of representation and recall. In C. Eastman, W. M. McCracken, \& W. C. Newstetter (Eds.), Design knowing and learning: cognition in design education (pp. 147-198). Amsterdam: Elsevier.

Eisner, E. (1979). The educational imagination. New York, NY: Macmillan.

Eisner, E. (1994). The educational imagination (2nd ed.). New York, NY: Macmillan.

Eisner, E. W. (1976). Educational connoisseurship and criticism: Their form and functions in educational evaluation. Journal of Aesthetic Education, 135-150.

Ellis, R. A., Steed, A. F., \& Applebee, A. C. (2006). Teacher conceptions of blended learning, blended teaching and associations with approaches to design. Australasian Journal of Educational Technology, 22(3), 312-335.

Ertmer, P., D., Stepich, C., York, A., Stickman, X. Wu, S., Zurek, \& Y. Goktas. (2008). How instructional design experts use knowledge and experience to solve ill-structured problems. Performance Improvement Quarterly, 21, 17-42.

Ertmer, P., Stepich, D., Flanagan F., Kocaman-Karoglu A., Reiner C., Reyes L., Santone A., \& Ushigusa, S. (2009). Impact of guidance on the problem-solving efforts of instructional design novices. Performance Improvement Quarterly, 21, 117-32.

Ertmer, P.A. (2005). Teacher pedagogical beliefs: The final frontier in our quest for technology integration? Educational Technology Research and Development, 53(4), 25-39.

Ertmer, P.A., \& Ottenbreit-Leftwich, A.T. (2010). Teacher technology change: How knowledge, confidence, beliefs, and culture intersect. Journal of Research on Technology in Education, 42(3), 255-284.

Gagné, R. M. (1985). The conditions of learning and theory of instruction (4th ed.). New York, NY: Holt, Rinehart $\&$ Winston.

Goodlad, J. (1994). Curriculum as a field of study. In T. Husén, \& T. Postlethwaite (Eds.), The international encyclopedia of education (pp. 1262-1267). Oxford: Pergamon Press.

Goodyear, P. (2005). Educational design and networked learning: patterns, pattern languages and design practice. Australasian Journal of Educational Technology, 21(1), 82-101.

Goodyear, P., \& Markauskaite, L. (2009). Teachers' design knowledge, epistemic fluency and reflections on students' experiences. Paper presented at the Higher Education Research and Development Society of Australasia (HERDSA) conference, Darwin, Australia.

Goodyear, P., \& Retalis, S. (2010). Learning, technology and design. In P. Goodyear \& S. Retalis (Eds.), Technology-enhanced learning: design patterns and pattern languages. Rotterdam: Sense Publishers. 
Gustafson, K. L., \& Branch, R. M. (2002). What is instructional design. Trends and Issues in Instructional Design and Technology (pp.16-25) Upper Saddle River, NJ: Pearson.

Handelzalts, A. (2009). Collaborative curriculum development in teacher design teams. Doctoral Thesis, University of Twente, Enschede.

Harris, J. \& Hofer, M. (2009). Instructional planning activity types as vehicles for curriculum-based TPACK development. In I. Gibson et al. (Eds.), Proceedings of Society for Information Technology \& Teacher Education International Conference 2009 (pp. 4087-4095). Chesapeake, VA: AACE. Retrieved from http://www.editlib.org/p/31298. Assessed 16 October 2014.

Hoogveld, A. W. M., Paas, F., \& Jochems, W. M. G. (2005). Training higher education teachers for instructional design of competency-based education: Product-oriented versus process-oriented worked examples. Teaching and Teacher Education, 21(3), 287-297. doi:10.1016/j.tate.2005.01.002.

Hoogveld, A. W. M., Paas, F., Jochems, W. M. G., \& van Merrienboer, J. J. G. Van. (2001). The effects of a webbased training in an instructional systems design approach on teachers' instructional design behavior, Computers in Human Behavior, 17, 363-371.

Horn, I. (2010). Teaching replays, teaching rehearsals, and re-visions of practice: Learning from colleagues in a mathematics teacher community. The Teachers College Record, 112(1), 225-259.

Huizinga, T., Handelzalts, A., Nieveen, N., \& Voogt, J. (in press). Teacher involvement in curriculum design: Need for support to enhance teachers' design expertise. Journal of Curriculum Studies, 46(1), 33-57.

Ingold, T. (2013). Making: Anthropology, archaeology, art, and architecture. New York, NY: Routledge.

Jonson, B. (2005). Design ideation: The conceptual sketch in the digital age. Design Studies, 26(6), 613-624.

Kali, Y., \& Ronen-Fuhrmann, T., (2011). Teaching to design educational technologies. The International Journal of Learning Technology, 6(1), 4-23.

Kali, Y., Goodyear, P., \& Markauskaite, L. (2011). Researching design practices and design cognition: Contexts, experiences and pedagogical knowledge-in-pieces. Learning, Media and Technology, 36(2), 129-149.

Kali, Y., Markauskaite, L., Goodyear, P., \& Ward, M-H. (2011). Bridging multiple expertise in collaborative design for technology-enhanced learning. Proceedings of the Computer Supported Collaborative Learning (CSCL) conference (pp. 831-835). Hong Kong: ISLS.

Kerr, S. T. (1981). How teachers design their materials: Implications for instructional design. Instructional Science, $10(4), 363-378$.

Kerr, S. T. (1983). Inside the black box: Making design decisions for instruction. British Journal of Educational Technology, 14(1), 45-58.

Kessels, J.W.M. (1999). A relational approach to curriculum design. In J.J.H. Van den Akker, R. Branch, K. Gustafson, N. Nieveen, \& Tj. Plomp (Eds.) Design and development methodology in education (pp. 5970). Dordrecht: Kluwer Academic Publishers.

Kirschner, P. A. (2002). Cognitive load theory: Implications of cognitive load theory on the design of learning. Learning and Instruction, 12(1), 1-10.

Kirschner, P., Carr, C., van Merriënboer, J., \& Sloep, P. (2002). How expert designers design. Performance Improvement Quarterly, 15(4), 86-104.

Koehler, M. J., \& Mishra, P. (2005). What happens when teachers design educational technology? The development of technological pedagogical content knowledge. Journal of Educational Computing Research, 32(2), 131152.

Koehler, M., Mishra, P., \& Yahya, K. (2007). Tracing the development of teacher knowledge in a design seminar: Integrating content, pedagogy and technology. Computers \& Education, 49(3), 740-762. doi:10.1016/j.compedu.2005.11.012

Laurillard, D. (2008). The teacher as action researcher: Using technology to capture pedagogic form. Studies in Higher Education, 33(2), 139-154.

Laurillard, D. (2012). Teaching as a design science: Building pedagogical patterns for learning and technology. New York, NY: Routledge.

Lave, J., \& Wenger, E. (1991). Situated learning: Legitimate peripheral participation. Cambridge: Cambridge University Press.

Lawson, B., \& Dorst, K. (2009). Design expertise. Oxford: Elsevier.

Le Dantec, C. A., \& DiSalvo, C. (2013). Infrastructuring and the formation of publics in participatory design. Social Studies of Science, 43(2), 241-264.

Lin, X., Schwartz, D. L., \& Bransford, J. (2007). Intercultural adaptive expertise: Explicit and implicit lessons from Dr. Hatano. Human Development, 50(1), 65-72. 
Linsey, J., Wood, K., \& Markman, A. (2008a). Increasing innovation: Presentation and evaluation of the WordTree design-by-analogy method. Paper presented at the ASME IDETC Design Theory and Methodology Conference, New York, NY.

Linsey, J., Wood, K., \& Markman, A. (2008b). Modality and representation in analogy. Artificial Intelligence for Engineering Design, Analysis and Manufacturing, 22(2), 85-100.

Lundwall, B., \& Johnson, B. (1994). The learning economy. Journal of Industry Studies, 1(2), 23-42.

Markauskaite, L., \& Goodyear, P. (2014). Tapping into the mental resources of teachers' working knowledge: Insights into the generative power of intuitive pedagogy. Learning, Culture and Social Interaction, 3(4), 237-251. doi: http://dx.doi.org/10.1016/j.lcsi.2014.01.001

Masterman, E., Jameson, J., \& Walker, S. (2009). Capturing teachers' experience of learning design through case studies. Distance Education, 30, 223-238.

McAndrew, P., Goodyear, P., \& Dalziel, J. (2006). Patterns, designs and activities: unifying descriptions of learning structures. International Journal of Learning Technology, 2(2/3), 216-242.

McKenney, S. (2013). Designing and researching technology enhanced learning for the zone of proximal implementation. Research in Learning Technology Supplement, 21,17374. http://dx.doi.org/10.3402/rlt.v21i0.17374.

McKenney, S., \& Reeves, T. C. (2012). Conducting educational research design. London: Routledge.

McKenney, S., Nieveen, N., \& van den Akker, J. (2006). Design research from the curriculum perspective. In J. van den Akker, K. Gravemeijer, S. McKenney \& N. Nieveen (Eds.), Educational design research (pp. 67-90). London: Routledge.

Mehalik, M. M., \& Schunn, C. D. (2006). What constitutes good design? A review of empirical studies of the design process. International Journal of Engineering Education, 22(3), 519-532.

Mishra, P., \& Koehler, M. (2006). Technological pedagogical content knowledge: A framework for teacher knowledge. Teachers College Record, 108(6), 1017-1054.

Mishra, P., Koehler, M. \& Zhao, Y. (2007). Faculty development by design, integrating technology in higher education. Scottsdale, AZ: Information Age Publishing.

Nelson, H. G., \& Stolterman, E. (2012). The design way: Intentional change in an unpredictable world. Cambridge, MA: MIT Press.

Nieveen, N., Van der Hoeven, M., Ten Voorde, M., Koopmans, A., \& Van Lanschot Hubrecht, V. (2013). Docent als ontwerper: Raamwerk voor doordenking ontwerptaken [Teacher designer: Framework for considering design tasks]. Enschede: SLO.

Otto, K. N., \& Wood, K. L. (2001). Product design: Techniques in reverse engineering and new product development. Upper Saddle River, NJ: Prentice Hall.

Pipek, V., \& Wulf, V. (2009). Infrastructuring: Toward an integrated perspective on the design and use of information technology. Journal of the Association for Information Systems, 10(5), 1.

Plattner, H., Meinel, C., \& Leifer, L. (2010). Design thinking: Understand-improve-apply. London: Springer.

Posner, G. J., \& Rudnitsky, A. N. (1994). Course design: A guide to curriculum development for teachers. White Plains, NY: Longman.

Prieto, L. P., Villagra-Sobrino, S., Jorrin-Abellan, I. M., Martinez-Mones, A., \& Dimitriadis, Y. (2011). Recurrent routines: Analyzing and supporting orchestration in technology-enhanced primary classrooms. Computers and Education, 57(1), 1214-1227.

Putnam, R. T., \& Borko, H. (2000). What do new views of knowledge and thinking have to say about research on teacher learning? Educational Researcher, 29(1), 4-15.

Razzouk, R., \& Shute, V. (2012). What is design thinking and why is it important? Review of Educational Research, 82(3), 330-348. doi:10.3102/0034654312457429.

Reder, L. M., \& Schunn, C. D. (1996). Metacognition does not imply awareness: Strategy choice is governed by implicit learning and memory. In L. M. Reder (Ed.) Implicit Memory and Metacognition (pp. 45-77). Mahwah, NJ: Erlbaum.

Ronen-Fuhrmann, T., Kali, Y., \& Hoadley, C. M. (2008). Helping education students understand learning through designing. Educational Technology, 48 (2), 26-33.

Rowland, G. (1992). What do instructional designers actually do? An initial investigation of expert practice. Performance Improvement Quarterly, 5, 65-86.

Sagy, O., \& Kali, Y. (2014). Teachers as design-researchers. Paper presented at the Annual Meeting of the American Educational Research Association, April 3-7, Philadelphia.

Sawyer, K. (2006). Educating for innovation. Thinking Skills and Creativity, 1, 41-48. 
Schoenfeld, A. H. (2010). How we think: A theory of goal-oriented decision making and its educational applications. New York: Routledge.

Schön, D. A. (1983). The reflective practitioner: how professionals think in action. New York, NY: Basic Books.

Schön, D. A. (1987). Educating the reflective practitioner: Toward a new design for teaching and learning in the professions. San Francisco, CA: Jossey-Bass.

Schwab, J. J. (1962). The concept of the structure of a discipline. Educational Record, 43(3), 197-205.

Shamir-Inbal, T., Dayan, J., \& Kali, Y. (2009). Assimilating online technologies into school culture. Interdisciplinary Journal of E-Learning and Learning Objects, 5, 207-334.

Shrager, J., \& Siegler, R. S. (1998). SCADS: A model of children's strategy choices and strategy discoveries. Psychological Science, 9(5), 405-410.

Simon, H. A. (1969/1996). The sciences of the artificial. ( $1^{\text {st }} / 3^{\text {rd }}$ eds.). Cambridge, MA: MIT Press.

Star, S. L., \& Ruhleder, K. (1996). Steps toward an ecology of infrastructure: Design and access for large information spaces. Information Systems Research, 7(1), 111-134.

Stempfle, J., \& Badke-Schaub, P. (2002). Thinking in design teams-an analysis of team communication. Design Studies, 23(5), 473-496.

Tseng, I., Moss, J., Cagan, J., \& Kotovsky, K. (2008). The role of timing and analogical similarity in the stimulation of idea generation in design. Design Studies, 29, 203-221.

Turnbull, D. (2000). Masons, tricksters and cartographers: comparative studies in the sociology of scientific and indigenous knowledge. Australia: Harwood Academic.

Ulrich, K. T., Eppinger, S. D., \& Goyal, A. (2011). Product design and development (Vol. 2). New York, NY: McGraw-Hill.

Van Merriënboer, J. J., \& Kirschner, P. A. (2012). Ten steps to complex learning: A systematic approach to fourcomponent instructional design. London: Routledge.

Visscher-Voerman, I., \& Gustafson, K. L. (2004). Paradigms in the theory and practice of education and training design. Educational Technology Research and Development, 52(2), 69-89.

Voogt, J. Fisser, P., Pareja Roblin, N., Tondeur, J.\& Van Braak, J. (2013a). Technological Pedagogical Content Knowledge (TPACK) - A review of the literature. Journal of Computer Assisted Learning, 29(2) 109-121.

Voogt, J., van Braak, J., Heitink, M., Verplanken, L., Fisser, P., \& Walraven, A. (2013b). Didactische ICTbekwaamheid van docenten [Pedagogical technology competencies of teachers]. Zoetermeer, the Netherlands: Kennisnet.

Voogt, J., Westbroek, H., Handelzalts, a., Walraven, a., McKenney, S., Pieters, J., \& De Vries, B. (2011). Teacher learning in collaborative curriculum design. Teaching and Teacher Education, 27(8), 1235-1244. doi:10.1016/j.tate.2011.07.003.

Walker, D. (1971). A naturalistic model for curriculum development. The School Review, 80(1), 51-65.

Wang, Q., Nieveen, N., \& van den Akker, J. (2007). Designing a computer support system for multimedia curriculum development in Shanghai. Educational Technology Research and Development, 55(3), 275295. 